\title{
水分特性曲線を用いて不飽和土の透気係数と 飽和度の関係を推定する関数モデルの考察
}

\author{
神谷浩二 $^{1} \cdot$ 井上光弘 ${ }^{2}$ \\ ${ }^{1}$ 正会員 岐阜大学准教授 工学部社会基盤工学科( ₹501-1193 岐阜市柳戸1-1) \\ E-mail : kkamiya@gifu-u.ac.jp \\ ${ }^{2}$ 鳥取大学准教授 乾燥地研究センター( ⿳ 厂 680-0001 鳥取市浜坂1390)
}

\begin{abstract}
本論文は，筆者らが提案した透気試験装置・手法を用いて，排水と吸水過程での水分特性曲線と透気係 数の実験的関係を調べつつ, 水分特性曲線から透気係数を推定する従来の関数モデル式の測定值への適合 性を分析したものである. Burdine と Mualemによる関数モデル式を比較して検討した結果, Burdine モデ ル式は，排水過程で測定した飽和度と透気係数の関係に比較的適合寸る傾向にあった. しかし, 間隙の屈 曲による透気係数への影響を表すパラメーター 值は土質などによって異なることが得られ, その最適值を 用いるとき両モデル式のいずれによっても排水・吸水の両過程での測定值を良好な精度で再現できること が判明した。 また, 最適な $\xi$ 值は, 水分特性曲線の形状と相関関係があることなどが明らかになった。
\end{abstract}

Key Words: air permeability coefficient, water characteristic curve, tortuosity factor, unsaturated soil

\section{1. まえがき}

不飽和土の透気係数は，不飽和透水係数，水分特 性曲線とともに不飽和地盤内の浸透挙動に影響を与 える重要な要因である. 西田ら ${ }^{1)}$ は，降雨浸透に伴う 斜面の安定性には透気係数と透水係数の関係も影響 することを示した。一方，Meiri ${ }^{2}$ などによる間隙空 気・間隙水の挙動を連成させた不飽和浸透流解析手 法では, 飽和度と透気係数の関係は重要な入力パラ メーターの一つである.

筆者ら ${ }^{3)}$ は, 不飽和土の透気係数を測定するための 室内試験装置・手法を提案した。これは, サクショ ンを与え飽和度を制御した試料層に空気を透過させ ることによって透気係数を求めるものである. 即ち, 間隙水の排水・吸水過程における水分特性曲線と透 気係数の両者を関係させて測定することができる.

本論文は, 飽和度と透気係数の関係を表す関数モデ ルについて検討したものである，室内試験によって 得られた飽和度と透気係数の離散的な関係を連続的 な関数で表現することは，任意の飽和度における透 気係数を得ることができ，また，上述の浸透流解析 手法において有用である.

測定した飽和度と透気係数の関係に指数関数など をフィッティングさせることによって，その関係を 表現する経験的関数モデルが, Yoshimi \& Osterberg ${ }^{4}$,
長田 ${ }^{5)}$, Stylianou \& De Vantier ${ }^{(0)}$ とよって示された. こ れらのモデルは, 式中に含まれる回帰係数を測定值 へのフィッティングによって決定しなければならな い. これに対比して, 水分特性曲線を用いて透気係 数を推定する半理論的な関数モデルが検討された. これは, 間隙径分布などの間隙構造に基づき透気係 数を表現して，それに間隙構造が反映された水分特 性曲線の表現式を代入することによって, 飽和度と 透気係数の関係を表す関数式を誘導したものである. この半理論的な関数モデルは, Brooks \& $\mathrm{Corey}^{7)}$, Lenhard \& Parker ${ }^{8)}$, Moldrup $ら^{9)}$, Dury $ら^{10)}$ によって 示されていて, Stylianou \& De Vantier ${ }^{6}$, Chen ら ${ }^{11)}$, Tuli \& Hopmans ${ }^{12}$ によって関数モデルの測定值への 適合性が検討された。 しかし, 水分特性曲線と透気 係数の関連が十分に検討されていない.

本論文は, 測定した水分特性曲線と透気係数の実 験的関係を調べるとともに, 従来の半理論的な関数 モデルの測定值への適合性を分析したものである. これによって, 比較的容易に得られる水分特性曲線 から透気係数を推定できるという関数モデルの利点 を明らかにでき, また, 浸透流解析における関数モ デルの利用方法への指針等に繋がると期待される.

以下では, 先ず, 従来の経験的関数モデルと半理 論的関数モデルのそれぞれを整理して示す. 次に, 砂質土とシルト質土について測定した飽和度と透気 
係数の関係に対して，水分特性曲線の相関関係など を調べるとともに，半理論的関数モデルの適合性や そのモデルの取り扱いについて検討した結果を示す。

\section{2. 飽和度と透気係数の関係を表す関数モデル}

\section{(1) 経験的な関数モデル}

測定した飽和度と透気係数の関係を指数関数など でフィッティングさせることによって表した関数モ デルを紹介する。なお，本論文では，この経験的モ デルの有用性などを検討していない.

Yoshimi \& Osterberg ${ }^{4}$ は, シルト質土を対象に, 次 式による実験的関係を示した.

$$
\log k_{\mathrm{a}}=a_{\mathrm{y}} \log \left[e\left(1-S_{\mathrm{r}} / 100\right)\right]+b_{\mathrm{y}}
$$

ここで, $k_{\mathrm{a}}(\mathrm{cm} / \mathrm{s})$ は不飽和土の透気係数, $e$ は間隙比, $S_{\mathrm{r}}(\%)$ は飽和度， $a_{\mathrm{y}}, b_{\mathrm{y}}$ は回帰係数である.

長田 ${ }^{5)}$ は，砂質土や火山灰質土を対象に，飽和度と 透気係数の関係には変移点なるものがあるとし, 次 式(2)のように変移点での飽和度 $S_{\mathrm{rt}}(\%)$ を境にして2 つの関係によって表現した.

$$
\begin{array}{ll}
S_{\mathrm{r}} \geq S_{\mathrm{rt}} ; & \log k_{\mathrm{a}}=a_{\mathrm{n} 1}\left(1-S_{\mathrm{r}} / 100\right)+b_{\mathrm{n} 1} \\
S_{\mathrm{r}} \leq S_{\mathrm{rt}} ; & \log k_{\mathrm{a}}=a_{\mathrm{n} 2}\left(1-S_{\mathrm{r}} / 100\right)+b_{\mathrm{n} 2}
\end{array}
$$

ここで， $a_{\mathrm{n} 1}, \quad b_{\mathrm{n} 1}, a_{\mathrm{n} 2}, b_{\mathrm{n} 2}$ は回帰係数である. 長田 ${ }^{5)}$ は， $a_{\mathrm{n} 1}>a_{\mathrm{n} 2}$ の関係にあることを示し，また， $a_{\mathrm{n} 1}$ と $a_{\mathrm{n} 2}$ の值の大きさは間隙径と間隙が曲がりくねったりす る屈曲に関連することを説明した。

Stylianou \& De Vantier ${ }^{6}$ は，経験的モデルは，後述 する半理論的モデルのように水分特性曲線の測定值 を必要としない利点があるとし，測定值に対する近 似式を次のように示した。

$$
\frac{k_{\mathrm{a}}}{k_{\mathrm{ad}}}=a_{\mathrm{s}}+b_{\mathrm{s}}\left(S_{\mathrm{r}} / 100\right)+c_{\mathrm{s}}\left(S_{\mathrm{r}} / 100\right)^{2}
$$

ここで， $k_{\mathrm{ad}}(\mathrm{cm} / \mathrm{s})$ は炉乾燥土の透気係数， $a_{\mathrm{s}}, b_{\mathrm{s}}, c_{\mathrm{s}}$ は回帰係数である.なお, Stylianou \& De Vantier は, 砂質土について, 式(3)による測定值へのフィッティ ングによって $, a_{\mathrm{s}}=1.105, b_{\mathrm{s}}=-2.576, c_{\mathrm{s}}=1.577 の$ 数值 を得ている6).

上述の経験的関数モデル式(1)〜(3)では, 式中の回 帰係数を決定するのに飽和度と透気係数の関係の測 定值が必要となる。これに対して，次述する半理論 的な関数モデルでは, 水分特性曲線から飽和度と透 気係数の関係が得られるという特徵がある.

\section{(2) 半理論的な関数モデル}

\section{a) Burdine モデルと Mualem モデル}

不飽和土の透気係数は，空気の粘性係数などの性
質とともに，間隙部分の大きさや屈曲の構造，飽和 度の影響を受ける. 不飽和透水係数を表す関数モデ ルとして用いられる Burdine モデル ${ }^{13)} と$ Mualem モデ ル ${ }^{14)}$ は，間隙構造をモデル化して不飽和透水係数と 関連付けたものであり，透気係数の場合について書 き改めると次のように総括的に表現される.

$$
\frac{k_{\mathrm{a}}}{k_{\mathrm{ad}}}=\left(1-S_{\mathrm{e}}\right)^{\xi}\left[\frac{\int_{d_{\mathrm{m}, \mathrm{i}}}^{d_{\mathrm{m}, \max }} d_{\mathrm{m}}{ }^{\beta} f\left(d_{\mathrm{m}}\right) d\left(d_{\mathrm{m}}\right)}{\int_{d_{\mathrm{m}, \text { min }}}^{d_{\mathrm{m} \text { max }}} d_{\mathrm{m}}{ }^{\beta} f\left(d_{\mathrm{m}}\right) d\left(d_{\mathrm{m}}\right)}\right]^{\eta}
$$

この式(4)の $S_{\mathrm{e}}$ は有効飽和度であり, 次式(5)によって 定義される.

$$
S_{\mathrm{e}}=\frac{S_{\mathrm{r}}-S_{\mathrm{r} 0}}{S_{\mathrm{rs}}-S_{\mathrm{r} 0}}
$$

ここで， $S_{\mathrm{r} 0}(\%)$ は残留飽和度， $S_{\mathrm{rs}}(\%)$ は最大飽和度で ある.また，式(4)の あは間隙の屈曲に影響を受ける パラメーター,$d_{\mathrm{m}, \max }(\mathrm{mm})$ は最大間隙径, $d_{\mathrm{m}, \mathrm{i}}(\mathrm{mm})$ は 空気で占められた間隙部分での最小径, $d_{\mathrm{m}, \mathrm{min}}(\mathrm{mm})$ は 最小間隙径, $d_{\mathrm{m}}(\mathrm{mm})$ は間隙径, $f\left(d_{\mathrm{m}}\right)$ は間隙径の分布 密度関数, $\beta$ と $\eta$ は間隙の連結性に影響されるパラ メーターである. Burdine モデルでは $\xi=2, \beta=2, \eta=1$ の数值が与えられ ${ }^{13)}$, Mualem モデルでは $\xi=0.5, \beta=1$, $\eta=2$ あ゙あ ${ }^{14)}$.

式(4)について，右辺の第1括弧の $\left(1-S_{\mathrm{e}}\right)^{\xi}$ は，間隙 (空気流)の屈曲の程度による透気係数への影響を表 したものであり， $S_{\mathrm{e}}$ の值が1に近くなるほどその項の 值が小さくなり空気流の屈曲が多くなることを表す. 第2括弧は, 間隙径分布や間隙の連結性による透気係 数への影響を表したものである.

次に, Burdine モデル $(\xi=2, \beta=2, \eta=1)$ と Mualem モ デル $(\xi=0.5, \beta=1, \eta=2)$ を比較する. 式(4)の第1括弧 について, $\left(1-S_{\mathrm{e}}\right)^{2}<\left(1-S_{\mathrm{e}}\right)^{0.5}$ の関係にあり, Mualem モデルの方の值が同じ有効飽和度のときに大きく, 空気流の屈曲が少なくなるように表し透気係数を大 きめに与える(後述の図ー1参照). また, Mualem モ デルの第1括弧の值は, 有効飽和度の変化によって Burdine モデルのときよりも緩やかに変化する．第2 括弧について, Burdine モデルでは，“間隙部分はま つすぐに連続した種々の直径の円管の集合体であ る”と仮定する毛管モデル ${ }^{15)}$ 基づき間隙径分布に よる透気係数への影響を表している.これに対し， Mualem モデルでは, 毛管モデルに加え “広くなった り狭くなったりする”瘤状の間隙部分の連結による 透気係数への影響も含んで表現される. 即ち, Burdine モデルと Mualem モデルの相違は, 空気流の屈曲に よる影響の表現法( $($ 值)の違い, 間隙の連結性による 影響の考慮の有無の違いにある。なお，上述の式(4) の右辺の第1括弧と第2括弧による透気係数への影響 
の度合いなどについては，本節のd)で後述する。

\section{b) 水分特性曲線と透気係数の関連付け}

毛管モデルの仮定に基づくと, 間隙径 $d_{\mathrm{m}}(\mathrm{mm})$ とサ クション $s(\mathrm{kPa})$ の関係は次式(6)のようである ${ }^{15)}$.

$$
d_{m}=\frac{4 T_{\mathrm{s}} \cos \beta}{s}
$$

ここで， $T_{\mathrm{s}}(\mathrm{N} / \mathrm{m})$ は水の表面張力， $\beta\left(^{\circ}\right)$ は水と土粒子 の接触角である。更に，毛管モデルに従い，式(4)の 間隙径の分布密度関数 $f\left(d_{\mathrm{m}}\right)$ は, 有効飽和度 $S_{\mathrm{e}}$ を用い て次のように表現することができる ${ }^{15)}$.

$$
f\left(d_{\mathrm{m}}\right)=\frac{d \theta}{d\left(d_{\mathrm{m}}\right)}=n\left(S_{\mathrm{rs}}-S_{\mathrm{r} 0}\right) \frac{d S_{\mathrm{e}}}{d\left(d_{\mathrm{m}}\right)}
$$

ここで， $\theta$ は体積含水率である.

式(6)の関係と式(7)の関係を式(4)に代入し, 更に, 式(6)に従い最大間隙径 $d_{\mathrm{m}, \max }$ のときのサクション $s$ に対応する有効飽和度を $S_{\mathrm{e}}=1$, 最小間隙径 $d_{\mathrm{m}, \min }$ に対 応するものを $S_{\mathrm{e}}=0$ として整理すると, 式(4)は次式(8) に書き改められる.

$$
\frac{k_{\mathrm{a}}}{k_{\mathrm{ad}}}=\left(1-S_{\mathrm{e}}\right)^{\xi}\left[\frac{\int_{S_{\mathrm{e}}}^{1} \frac{1}{s^{\beta}} d S_{\mathrm{e}}}{\int_{0}^{1} \frac{1}{s^{\beta}} d S_{\mathrm{e}}}\right]^{\eta}
$$

従って, サクション $s$ と有効飽和度 $S_{\mathrm{e}}$ の関係による 水分特性曲線を用いて式(8)の $s$ を $S_{\mathrm{e}}$ に置き換えるこ とによって, 飽和度と透気係数の関係を表すことが できる。

\section{c) 水分特性曲線を表す関数式}

式(8)に水分特性曲線を表す関数式を代入すること によって，飽和度と透気係数の関係による関数モデ ルを導くことができる。この関係を導くための水分 特性曲線の関数式として, Brooks \& Corey $^{7)}$ の式, van-Genuchten $^{16)}$ の式, Kosugi ${ }^{17)}$ の式などが利用されて (る ${ }^{6)}$. 12) 本論文では, 後述の図ー3に示すように測 定值に対して良好な関係で近似できた次の van-Genuchten 式(9)を用いる。

$$
S_{\mathrm{e}}=\frac{S_{\mathrm{r}}-S_{\mathrm{r} 0}}{S_{\mathrm{rs}}-S_{\mathrm{r} 0}}=\frac{1}{\left[1+(\alpha s)^{n^{*}}\right]^{m}}
$$

ここで, $\alpha(1 / \mathrm{kPa}), n^{*}$ と $m(0<m<1)$ は未知パラメータ 一であり，式(9)を測定值にフィッティングさせるこ とによって得られる。また，式(8)に式(9)の関係を代 入するとき, $n$ とと $m$ の関係には, Burdine モデル(式 (8)の $\xi=2, \beta=2, \eta=1)$ に代入する場合は $m=1-2 / n^{*}$ の関 係が用いられ，Mualem モデル $(\xi=0.5, \beta=1, \eta=2)$ の場 合は $m=1-1 / n^{*}$ 関係が用いられる ${ }^{16)}$. 以下では，式 (9)の $m$ について，式(8)を Burdine モデルで使用する 場合は $m_{\mathrm{B}}$, Mualem モデルの場合は $m_{\mathrm{M}}$ と表記する.

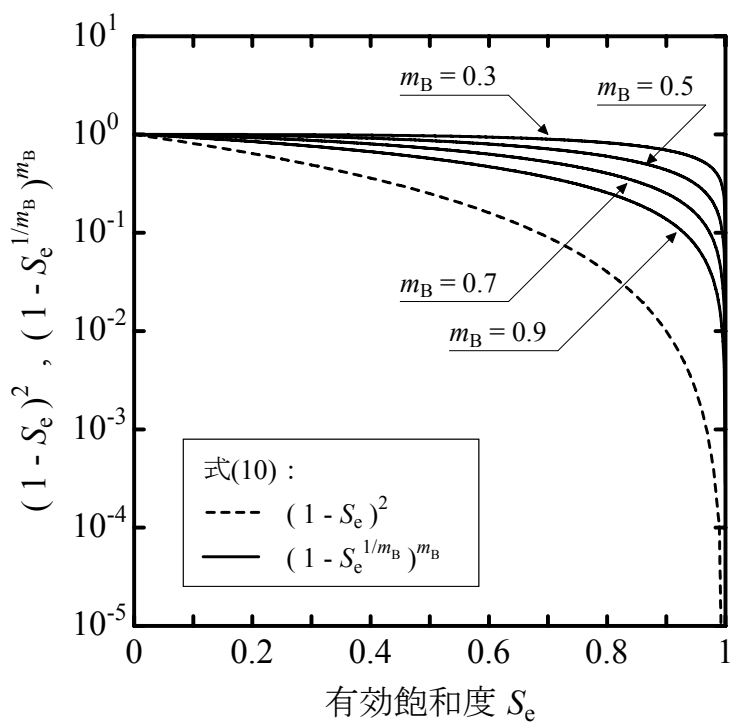

図－1(a) Burdine モデル式(10)の第 1 ・第 2 括弧の值

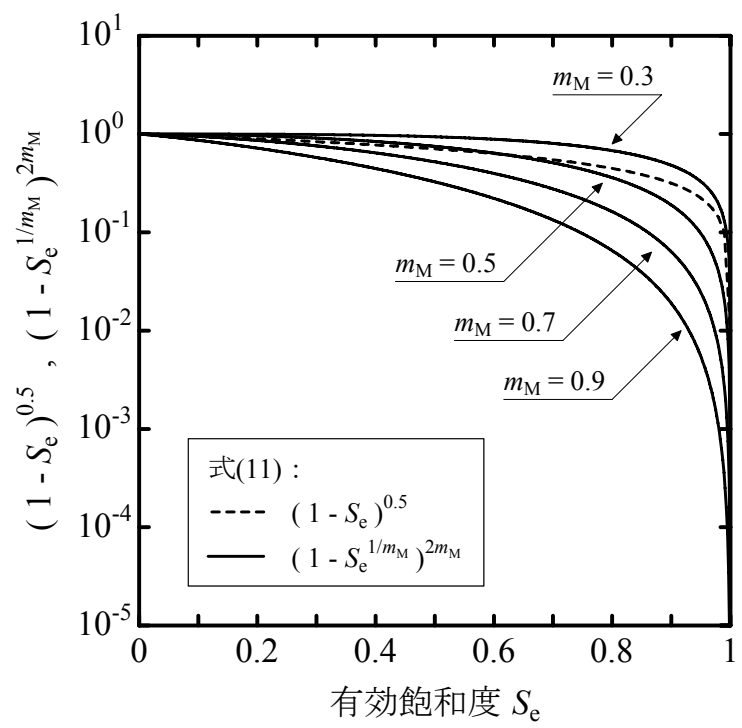

図－1(b) Mualem モデル式(11)の第 1 • 第 2 括弧の值

\section{d) 飽和度と透気係数の関係}

式(8)の関係に van-Genuchten 式(9)の関係を代入し て整理すると, Burdine モデルでは次の式(10)による 有効飽和度 $S_{\mathrm{e}}$ と透気係数 $k_{\mathrm{a}}$ の関係が得られ, Mualem モデルでは次式(11)の関係が得られる.

$$
\begin{gathered}
k_{\mathrm{a}} / k_{\mathrm{ad}}=\left(1-S_{\mathrm{e}}\right)^{2}\left(1-S_{\mathrm{e}}^{1 / m_{\mathrm{B}}}\right)^{m_{\mathrm{B}}} \\
k_{\mathrm{a}} / k_{\mathrm{ad}}=\left(1-S_{\mathrm{e}}\right)^{0.5}\left(1-S_{\mathrm{e}}^{1 / m_{\mathrm{M}}}\right)^{2 m_{\mathrm{M}}}
\end{gathered}
$$

透気係数 $k_{\mathrm{a}}$ と飽和度 $S_{\mathrm{r}}$ の関係は, 炉乾燥土の透気係 数 $k_{\mathrm{ad}}$, 水分特性曲線から推定される $S_{\mathrm{rs}}$ と $S_{\mathrm{r} 0}, m_{\mathrm{B}}$ あ るいは $m_{\mathrm{M}}$ の值によって決定される.

図-1は，式(10)と式(11)の各右辺の第1括弧と第2 括弧のそれぞれの值を有効飽和度 $S_{\mathrm{e}}$ との関係によっ 
て整理して示したものであり， $m_{\mathrm{B}}$ あるいは $m_{\mathrm{M}}$ の值 に0.3，0.5，0.7，0.9をそれぞれ代入したときの例を 示した. 式(10)と式(11)の第2括弧の值は，同じ有効 飽和度の大きさのとき, $m_{\mathrm{B}}$ あるいは $m_{\mathrm{M}}$ の值が小さ くなるほど大きくなる. 一方, 両式の第1括弧と第2 括弧を比較すると, Burdine モデルによる式(10)では, 同じ有効飽和度のときに第2括弧の值は第1括弧より も大きくなり，第2括弧の方が透気係数を大きめに与 える. Mualem モデルによる式(11)では，第2括弧の值 は， $m_{\mathrm{M}}$ 值が 0.5 程度よりも大きいときには第 1 括弧よ りも小さくなる特徵がある。

\section{3. 水分特性曲線と透気係数}

筆者らが提案した透気試験装置・手法 ${ }^{3)}$ の概要は次 のとおりである. 装置の概要図を示す図ー2において, 先ず, ビューレット内の空気圧力を真空ポンプで減 少させることによって，ある含水比の試料層の側面 からサクションを与え, 飽和度が一定になるように 制御する。なお, サクションを与えてから試料層内 の水分移動が無くなる(平衡状態)までの時間には, サ クション・飽和度の大きさによっても異なるが，本 論文で示す砂質土試料では数時間〜6時間程度, シル 卜質土試料では5時間〜12時間程度が必要であった。 平衡状態は，試料層に吸排水させるビューレット内 の水位変化の有無によって確認される. そして, 空 気コンプレッサーから供給される圧縮空気をある一 定の空気圧に調節して送気することによって, 空気 を試料層中に鉛直下向きで透過させる，そのとき， 試料層上端と下端の空気圧力水頭の差, 透過した空 気の流量をそれぞれ測定して，ダルシー式に基づい て透気係数は求められる. 即ち, この装置・手法で は，ある飽和度・サクションのときの透気係数を得 ることができ, 同時に水分特性曲線も得られる特徵 がある。透気試験装置・手法の詳細は参考文献3)を 参照されたい.

\section{(1) 水分特性曲線}

図一 3 は, 透気試験時に測定された飽和度 $S_{\mathrm{r}}$ とサク ション $s$ の関係を示したものである. 測定試料は, 鳥取砂丘砂(試料層の間隙比 $e=0.744)$, 長良川砂質土 $(e=0.784)$, 豊浦砂 $(e=0.855)$, 長良川シルト質土 $(e=0.776)$ の 4 種類である ${ }^{3)}$. その測定值は, 初期に $S_{\mathrm{r}}$ $=80 \%$ 程度以上の高飽和度に設定した試料層に, サ クションを段階的に増加させながら与える排水過程 で透気試験を行い, サクション増加に伴う飽和度変 化が殆じ生じなくなったときから，サクションを段 階的に減少させる吸水過程で透気試験を行ったとき

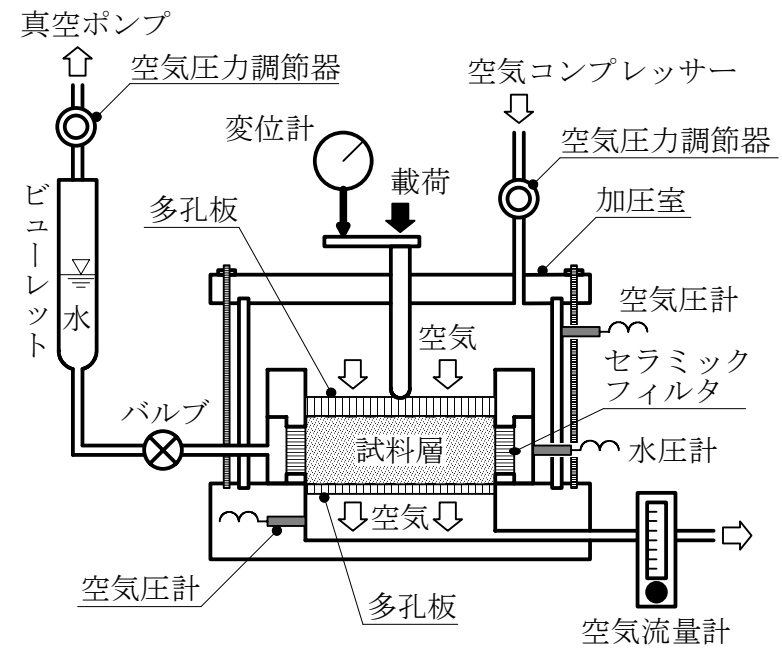

図-2 透気試験装置の概要図 ${ }^{3)}$

に得られたものである。また，各試料について同じ 間隙比のときの試料層を2回作製しそれぞれ測定し た. 図中の○印(排水過程)と $\square$ 印(吸水過程)は, その ときの飽和度あるいはサクションのときに透気が生 じたことを表し，○印(排水過程)と口印(吸水過程)は 透気が生じなかったことを表す.

また，図ー3の破線と実線は, van-Genuchten の式(9) を測定值にフィッティングさせて表したものであり， 式(8)を Burdine モデルで使用するとき(式(9)で $m=m_{\mathrm{B}}$ としたとき)の関係と Mualem モデルのとき $\left(m=m_{\mathrm{M}}\right.$ と したとき)の関係をそれぞれ示したものである。なお， 残留飽和度 $S_{\mathrm{r} 0}$ の值は, 排水と吸水過程で同じになる ように推定した. 表一1には, 式(9)による測定值への フィッティングによって得られた $S_{\mathrm{r} 0}, S_{\mathrm{rs}}, \alpha, n^{*}$ の 值を示し, 後述の式(12) と式(13)で求められる変曲点 サクション $s_{\mathrm{p}}$ と変曲点飽和度 $S_{\mathrm{rp}}$ の值を併記した. 式 (9)による関係は, Burdine モデルと Mualem モデルの いずれの場合での関係によっても測定值に対して合 致する.

\section{(2) 推定パラメーター $S_{\mathrm{rs}}, \quad S_{\mathrm{r} 0}, m_{\mathrm{B}} \cdot m_{\mathrm{M}}$}

上述の式(10)と式(11)のそれぞれによって与えら れる透気係数の值の差は, Burdine と Mualem モデル による間隙構造のモデル化の方法の相違とともに, 各モデルのときに水分特性曲線表現式(9)を測定值に フィッティングさせることによって推定される $S_{\mathrm{rs}}$, $S_{\mathrm{r} 0}, m\left(m_{\mathrm{B}}, m_{\mathrm{M}}\right)$ の值の差によっても生じることが予 想される.

表ー1によれば, Burdine と Mualem モデルのそれ ぞれの場合で推定された最大飽和度 $S_{\mathrm{rs}}$, 残留飽和度 $S_{\mathrm{r} 0}$ のそれぞれの值は, 両モデルによる差が殆どない. 次に, 図ー4は, Burdine モデルでの $m_{\mathrm{B}}$ と Mualem モ 

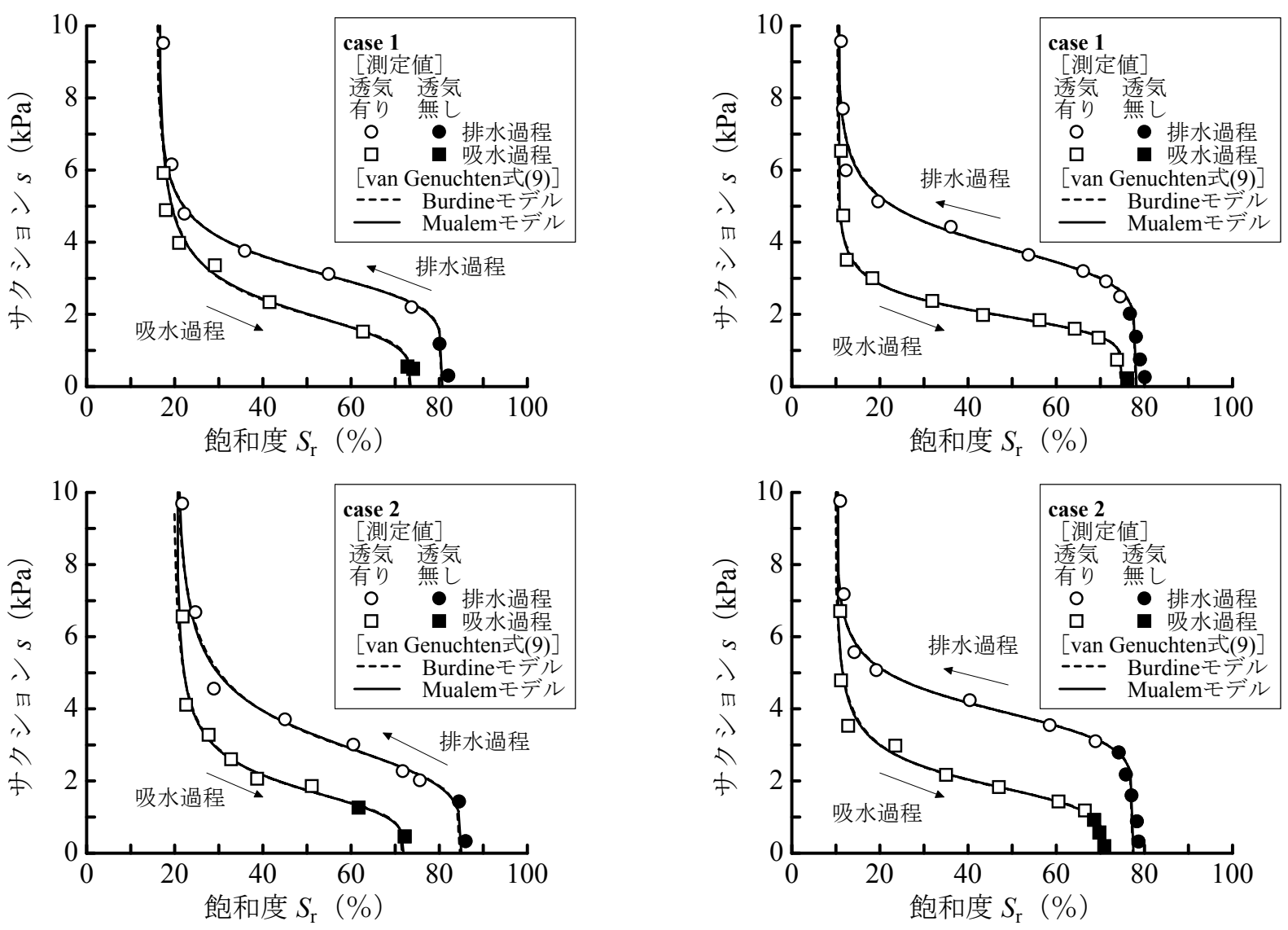

図－3(a) 水分特性曲線(鳥取砂丘砂)

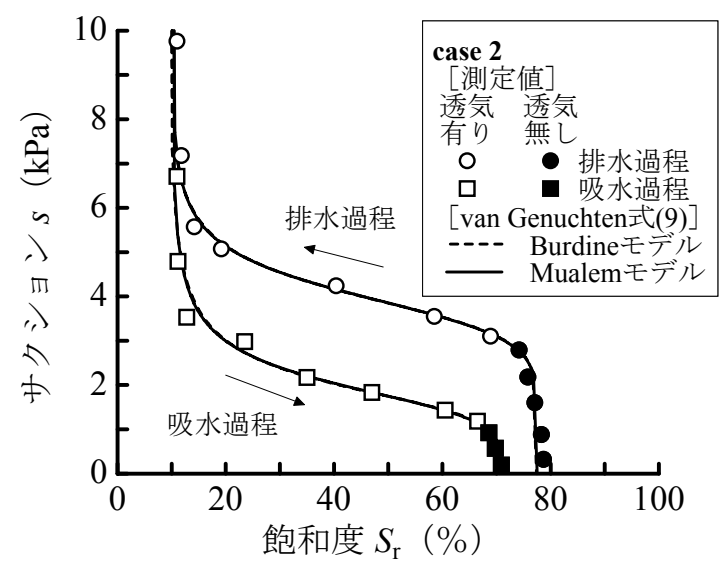

図－3(c) 水分特性曲線(豊浦砂)
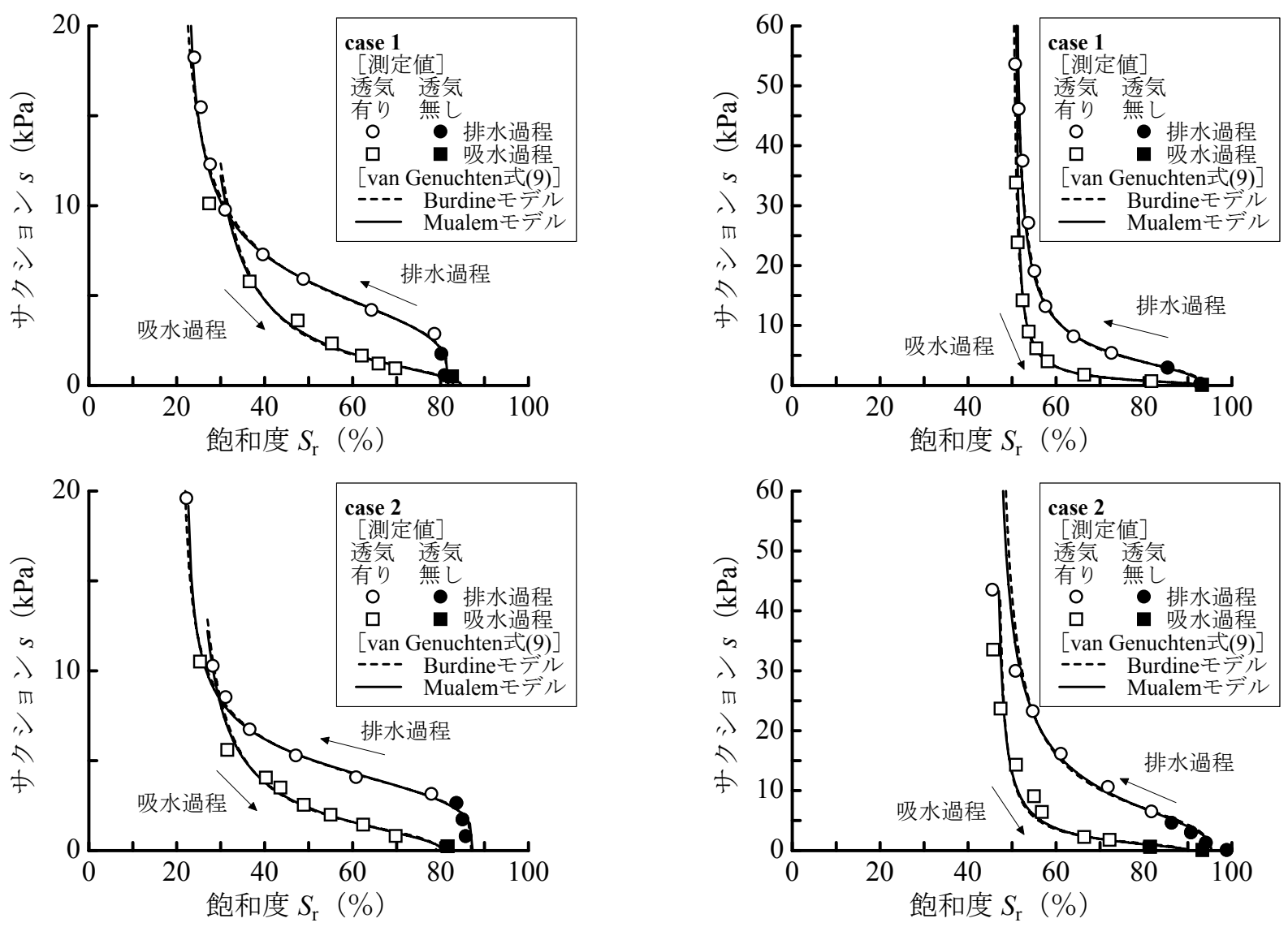

図－3(b) 水分特性曲線(長良川砂質土)

図－3 (d) 水分特性曲線(長良川シルト質土) 
表－1 van-Genuchten による式(9)の推定パラメーター $S_{\mathrm{r} 0}, S_{\mathrm{rs}}, \alpha, n^{*}$ おび変曲点サクション $s_{\mathrm{p}}$, 変曲点飽和度 $S_{\mathrm{rp}}$

\begin{tabular}{|c|c|c|c|c|c|c|c|c|c|c|c|c|c|c|}
\hline \multirow[b]{2}{*}{ 試料名称 } & \multirow[b]{2}{*}{ case } & \multirow[b]{2}{*}{ 過程 } & \multicolumn{6}{|c|}{ Burdine モデルの場合 } & \multicolumn{6}{|c|}{ Mualem モデルの場合 } \\
\hline & & & $\begin{array}{c}S_{\mathrm{r} 0} \\
(\%) \\
\end{array}$ & $\begin{array}{c}S_{\mathrm{rs}} \\
(\%)\end{array}$ & $\begin{array}{c}\alpha \\
(1 / \mathrm{kPa}) \\
\end{array}$ & $n^{*}$ & $\begin{array}{c}S_{\mathrm{p}} \\
(\mathrm{kPa})\end{array}$ & $\begin{array}{l}S_{\mathrm{rp}} \\
(\%)\end{array}$ & $\begin{array}{c}S_{\mathrm{r} 0} \\
(\%)\end{array}$ & $\begin{array}{c}S_{\mathrm{rs}} \\
(\%)\end{array}$ & $\begin{array}{c}\alpha \\
(1 / \mathrm{kPa}) \\
\end{array}$ & $n^{*}$ & $\begin{array}{c}S_{\mathrm{p}} \\
(\mathrm{kPa})\end{array}$ & $\begin{array}{c}S_{\mathrm{rp}} \\
(\%) \\
\end{array}$ \\
\hline \multirow{4}{*}{ 鳥取砂丘砂 } & \multirow{2}{*}{1} & 排水 & 15.6 & 80.6 & 0.33 & 6.6 & 3.04 & 55.7 & 16.1 & 80.7 & 0.32 & 6.1 & 3.07 & 54.9 \\
\hline & & 吸水 & 15.6 & 73.3 & 0.54 & 4.7 & 1.85 & 54.3 & 16.1 & 73.5 & 0.50 & 4.2 & 1.89 & 53.5 \\
\hline & \multirow{2}{*}{2} & 排水 & 19.4 & 84.7 & 0.36 & 5.0 & 2.79 & 62.4 & 20.2 & 85.0 & 0.33 & 4.6 & 2.84 & 61.5 \\
\hline & & 吸水 & 19.4 & 71.6 & 0.63 & 4.6 & 1.58 & 54.7 & 20.2 & 71.9 & 0.58 & 4.1 & 1.60 & 54.0 \\
\hline \multirow{4}{*}{$\begin{array}{l}\text { 長良川 } \\
\text { 砂質土 }\end{array}$} & \multirow[t]{2}{*}{1} & 排水 & 19.7 & 81.7 & 0.23 & 4.0 & 4.33 & 63.5 & 21.7 & 81.8 & 0.20 & 3.6 & 4.49 & 62.2 \\
\hline & & 吸水 & 19.7 & 83.0 & 1.02 & 2.7 & 0.98 & 72.4 & 21.7 & 84.9 & 0.79 & 1.9 & 0.86 & 74.2 \\
\hline & \multirow[t]{2}{*}{2} & 排水 & 20.8 & 87.0 & 0.26 & 4.5 & 3.88 & 65.9 & 22.0 & 87.3 & 0.23 & 4.1 & 3.98 & 64.7 \\
\hline & & 吸水 & 20.8 & 79.1 & 0.86 & 2.9 & 1.16 & 67.6 & 22.0 & 80.3 & 0.69 & 2.1 & 1.08 & 68.4 \\
\hline \multirow{4}{*}{ 豊浦砂 } & \multirow[t]{2}{*}{1} & 排水 & 9.9 & 78.1 & 0.27 & 7.5 & 3.76 & 51.0 & 10.2 & 78.2 & 0.26 & 7.1 & 3.80 & 50.2 \\
\hline & & 吸水 & 9.9 & 74.8 & 0.52 & 6.6 & 1.91 & 50.0 & 10.2 & 75.0 & 0.50 & 6.1 & 1.93 & 49.2 \\
\hline & \multirow{2}{*}{2} & 排水 & 9.5 & 77.4 & 0.26 & 8.3 & 3.86 & 49.6 & 9.9 & 77.5 & 0.25 & 7.9 & 3.89 & 48.9 \\
\hline & & 吸水 & 9.5 & 70.3 & 0.56 & 5.2 & 1.77 & 49.1 & 9.9 & 70.6 & 0.53 & 4.7 & 1.80 & 48.3 \\
\hline \multirow{4}{*}{$\begin{array}{l}\text { 長良川 } \\
\text { シルト質土 }\end{array}$} & & 排水 & 49.6 & 92.8 & 0.30 & 3.2 & 3.38 & 82.9 & 50.5 & 93.1 & 0.24 & 2.5 & 3.41 & 82.5 \\
\hline & & 吸水 & 49.6 & 93.3 & 1.73 & 2.8 & 0.58 & 85.2 & 50.5 & 93.6 & 1.34 & 2.0 & 0.54 & 85.4 \\
\hline & \multirow{2}{*}{2} & 排水 & 46.1 & 94.6 & 0.16 & 3.3 & 6.30 & 82.9 & 45.7 & 95.4 & 0.13 & 2.5 & 6.09 & 83.2 \\
\hline & & 吸水 & 46.1 & 88.8 & 0.86 & 3.0 & 1.17 & 80.0 & 45.7 & 90.3 & 0.79 & 2.0 & 0.89 & 82.1 \\
\hline
\end{tabular}

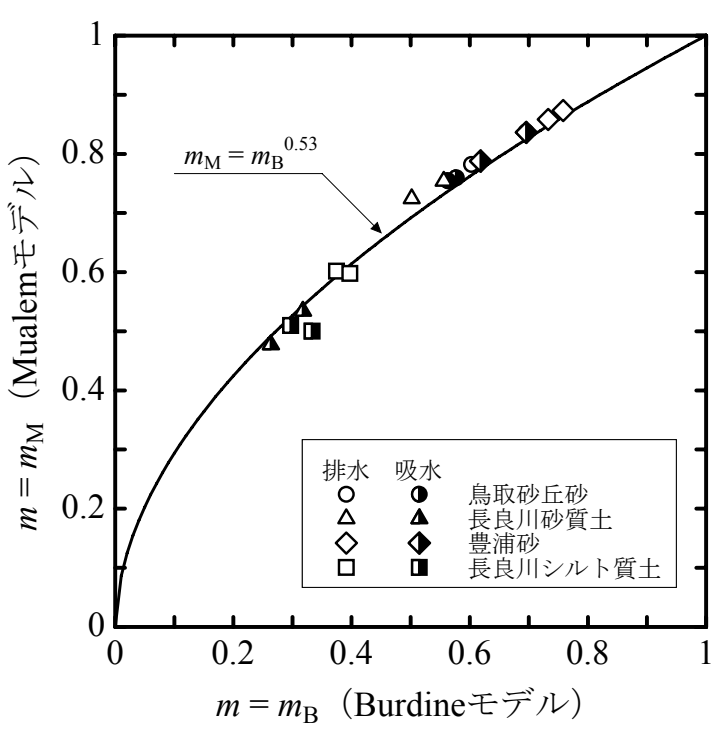

図-4 $m_{\mathrm{B}}, m_{\mathrm{M}}$ の推定值

デルでの $m_{\mathrm{M}}$ の值を比較したものである. $m_{\mathrm{M}}$ 值は $m_{\mathrm{B}}$ 值よりも大きくなり, 図中に実線で近似線を示した ように， $m_{\mathrm{M}}$ の值は $m_{\mathrm{B}}$ をおおよそ $1 / 2$ 乗したときの值 にほぼ等しい関係にある。この関係を用いて，上述 の Burdine モデル式(10)と Mualem モデル式(11)の右 辺第2括弧の $\left(1-S_{\mathrm{e}}^{1 / m_{\mathrm{B}}}\right)^{m_{\mathrm{B}}}$ と $\left(1-S_{\mathrm{e}}^{1 / m_{\mathrm{M}}}\right)^{2 m_{\mathrm{M}}}$ の值を試算 寸ると，同じ有効飽和度のときに式(11)の第2括弧の 值は式(10)のそれよりもより小さくなる. 即ち, 間隙 の連結性を考慮した Mualem モデルの第2括弧は,

Burdine モデルの第2括弧に比べて透気係数の值を小 さめに与える特徵がある(上述の図ー1を参照. 例え ば, $m_{\mathrm{B}}=0.5$ のときと $m_{\mathrm{M}}=m_{\mathrm{B}}{ }^{0.53} \fallingdotseq 0.7$ のきを比較 $)$.

\section{(3) 透気が生じるときのサクション・飽和度範囲}

図一3に示したような水分特性曲線について, 排水 過程の高飽和度側においてサクション増加に伴い飽 和度が急に低下し始めるときのサクションは空気侵 入值と呼ばれ, 吸水過程の高飽和度側でサクション 減少に伴い飽和度が変化しなくなるときのサクショ ンは水侵入值と呼ばれる ${ }^{18)}$ 。また, 本論文では, 両 過程において, van-Genuchten 式(9)による曲線形状が 凸形から凹形に変化するときの境界であり, 水分特 性曲線の勾配 $d s / d S_{\mathrm{r}}$ の值が最小となるときのサクシ ヨンと飽和度を変曲点サクション $s_{\mathrm{p}}(\mathrm{kPa})$ と変曲点飽 和度 $S_{\mathrm{rp}}(\%)$ として定義する. 式(9)に基づくと， $s_{\mathrm{p}}$ と $S_{\mathrm{rp}}$ は, Burdine モデルのときは次式(12)によって表さ れ，Mualem モデルのときは次式(13)によって表され $ろ^{19)}$.

$$
\begin{gathered}
S_{\mathrm{p}}=\frac{1}{\alpha}, \quad S_{\mathrm{rp}}=\frac{S_{\mathrm{rs}}-S_{\mathrm{r} 0}}{2^{m_{\mathrm{B}}}}+S_{\mathrm{r} 0} \\
S_{\mathrm{p}}=\frac{m_{\mathrm{M}}{ }^{1-m_{\mathrm{M}}}}{\alpha}, \quad S_{\mathrm{rp}}=\frac{S_{\mathrm{rs}}-S_{\mathrm{r} 0}}{\left(1+m_{\mathrm{M}}\right)^{m_{\mathrm{M}}}}+S_{\mathrm{r} 0}
\end{gathered}
$$

上述の表一1には，式(12)と式(13)によって求めた変 曲点サクション $s_{\mathrm{p}}$ と変曲点飽和度 $S_{\mathrm{rp}}$ の值を示した.

さて, 砂質土について示した図ー3 (a)〜 (c) によれ ば，排水過程では空気侵入值よりも大きなサクショ ン範囲のときに透気が生じ, 吸水過程では水侵入值 よりも大きいときに透気が生じる傾向がある. 一方, 表一1を参照して, 排水と吸水過程のいずれでも飽和 度が最大飽和度 $S_{\mathrm{rs}}$ よりも小さい範囲のときに透気が 生じる. $S_{\mathrm{rs}}$ から $S_{\mathrm{r}}=100 \%$ の範囲では, 間隙空気が存 在してもそれが気泡として封入されていたりして, 
連続した“空気流のみち”が形成されないため，透 気が生じないと考えられる。

次に，シルト質土について示した図ー3(d)によれ ば，表一1を参照して，排水と吸水の両過程で，変曲 点サクション $s_{\mathrm{p}}$ よりも大きいサクション範囲のとき, また, 変曲点飽和度 $S_{\mathrm{rp}}$ よりも小さい飽和度範囲のと きに透気が生じる傾向にあり，上述の砂質土での傾 向と異なる．砂質土に比べて細粒分含有率の高いシ ルト質土では3), サクションが空気侵入值を超えて飽 和度が低下し始めたときにマクロな間隙部分が空気 で占められ始めるが，細粒分によって形成される間 隙部分が水で占められていて連続した “空気流のみ ち”が形成され難いため, 空気侵入值よりも大きな 変曲点サクションを超えるまで透気が生じないこと が想像される。この結果, 関数モデル式(10)と式(11) をシルト質土について用いる場合には，式中の有効 飽和度 $S_{\mathrm{e}}$ を次式(14)で定義する修正有効飽和度 $S_{\mathrm{ep}}$ に 置き換えたときの式を用いることが適切であると考 えた。

$$
S_{\mathrm{ep}}=\frac{S_{\mathrm{r}}-S_{\mathrm{r} 0}}{S_{\mathrm{rp}}-S_{\mathrm{r} 0}}=\frac{S_{\mathrm{rs}}-S_{\mathrm{r} 0}}{S_{\mathrm{rp}}-S_{\mathrm{r} 0}} S_{\mathrm{e}}
$$

\section{4. 透気係数モデルの測定值への適合性}

\section{(1) 飽和度と透気係数の関係}

図一5は，測定した飽和度と透気係数の関係 ${ }^{3}$ を示 したものであり，図中の破線と実線は，図一3の水分 特性曲線表現式(9)の測定值に対するフィッティング によって得られたパラメーター $S_{\mathrm{rs}}, S_{\mathrm{rp}}, S_{\mathrm{r} 0}, m_{\mathrm{B}}, m_{\mathrm{M}}$ の值を用いて, Burdine モデル式(10)と Mualem モデ ル式(11)のそれぞれの関係を重ね合わせて示したも のである。ただし，式(10)と式(11)に含まれる炉乾燥 土の透気係数 $k_{\mathrm{ad}}$ の值には測定值を用い, 図一5には $k_{\mathrm{ad}}$ の值を $S_{\mathrm{r}}=0 \%$ に対して示した。 なお，長良川シル 卜質土については，上述のとおり，式(10)と式(11)の $S_{\mathrm{e}}$ を式(14)による $S_{\mathrm{ep}}$ に置き換えたときの式による関 係を示した。

均等な粒度をもつ鳥取砂丘砂と豊浦砂では，飽和 度と透気係数の関係は, 排水と吸水の過程の違いに よってヒステリシスを生じる傾向があり ${ }^{3)}$, 同じ飽和 度のとき吸水過程での透気係数の值は排水過程での ものより大きくなる。長良川砂質土と長良川シルト 質土では，ヒステリシスが殆じ生じない。また，透 気係数は，低飽和度側では飽和度変化によって緩や かに変化するが，高飽和度側では僅かな飽和度変化 に対して大きく変化する.

\section{(2) 関数モデルの適合性}

図ー5によれば，Mualem モデル式(11)に比べると， Burdine モデル式(10)の方が同じ飽和度のときの透気 係数を小さめに与える. 次に, 排水過程において, 砂質土とシルト質土のいずれでも式(10)による測定 值への適合性が高くなる傾向にある. 吸水過程にお いて, 鳥取砂丘砂と豊浦砂では両式による透気係数 の值が測定值よりも小さめにずれるが，いずれの試 料についても式(10)に比べれば式(11)による関係が 測定值に近めである.

Burdine モデル式(10)と Mualem モデル式(11)の相違 の一つは，2.（2）の a)で上述したように, 間隙の連 結性による透気係数への影響の考慮の有無にあった. 図一3に示した水分特性曲線において, 縦軸のサクシ ヨン $s$ を上述の式(6)によって間隙径 $d_{\mathrm{m}}$ に換算するこ とによって間隙径分布を推定できるが ${ }^{15)}$ ，水分特性 曲線のヒステリシスのため排水と吸水過程で推定さ れる間隙径分布は異なる。ヒステリシスの原因の一 つにはインクビン効果が指摘されている。これは, “広くなったり狭くなったりする”瘤状の間隙部分 において，排水過程でのサクションの大きさは狭い 間隙部分によって影響を受け，また，広い間隙部分 の体積が狭い部分の評価に含まれることを表したも のである. 従って, 排水過程での間隙径分布は, 吸 水過程でのものに比べると, 小さめの間隙径の分布 頻度が高くなるような形状をもつ ${ }^{15)}$. 即ち, 排水過 程での間隙径分布は間隙の連結性による影響を含ん だものとみることもできる。このため，図一5の排水 過程では，間隙の連結性による影響を考慮していな いBurdine モデル式(10)によっても測定值への適合性 が高くなる。また，吸水過程での間隙径分布(水分特 性曲線)を用いる場合には，間隙の連結に関する補正 が必要であるため, それを考慮した Mualem モデル 式(11)が測定值に近くなるのではないかと考えられ る.

\section{(3) 水分特性曲線の表現式の選択による影響}

水分特性曲線の表現式としての van-Genuchten 式 (9)に対し, Brooks \& Corey 式は次のように表される.

$$
S_{\mathrm{e}}=\frac{S_{\mathrm{r}}-S_{\mathrm{r} 0}}{S_{\mathrm{rs}}-S_{\mathrm{r} 0}}=\left(\frac{s_{\mathrm{e}}}{s}\right)^{\lambda}
$$

ここで, $s_{\mathrm{e}}(\mathrm{kPa})$ は空気侵入值, $\lambda$ は土の種類によって 決まるパラメーターである。図一6は，鳥取砂丘砂を 例に, 図一3(a) (case 1. Mualem モデルの場合)に式 (15)による関係を測定值にフィッティングさせて重 ね併せて示したものである。図一6のように，いずれ の試料についても測定值や式(9)に比べると，式(15) 

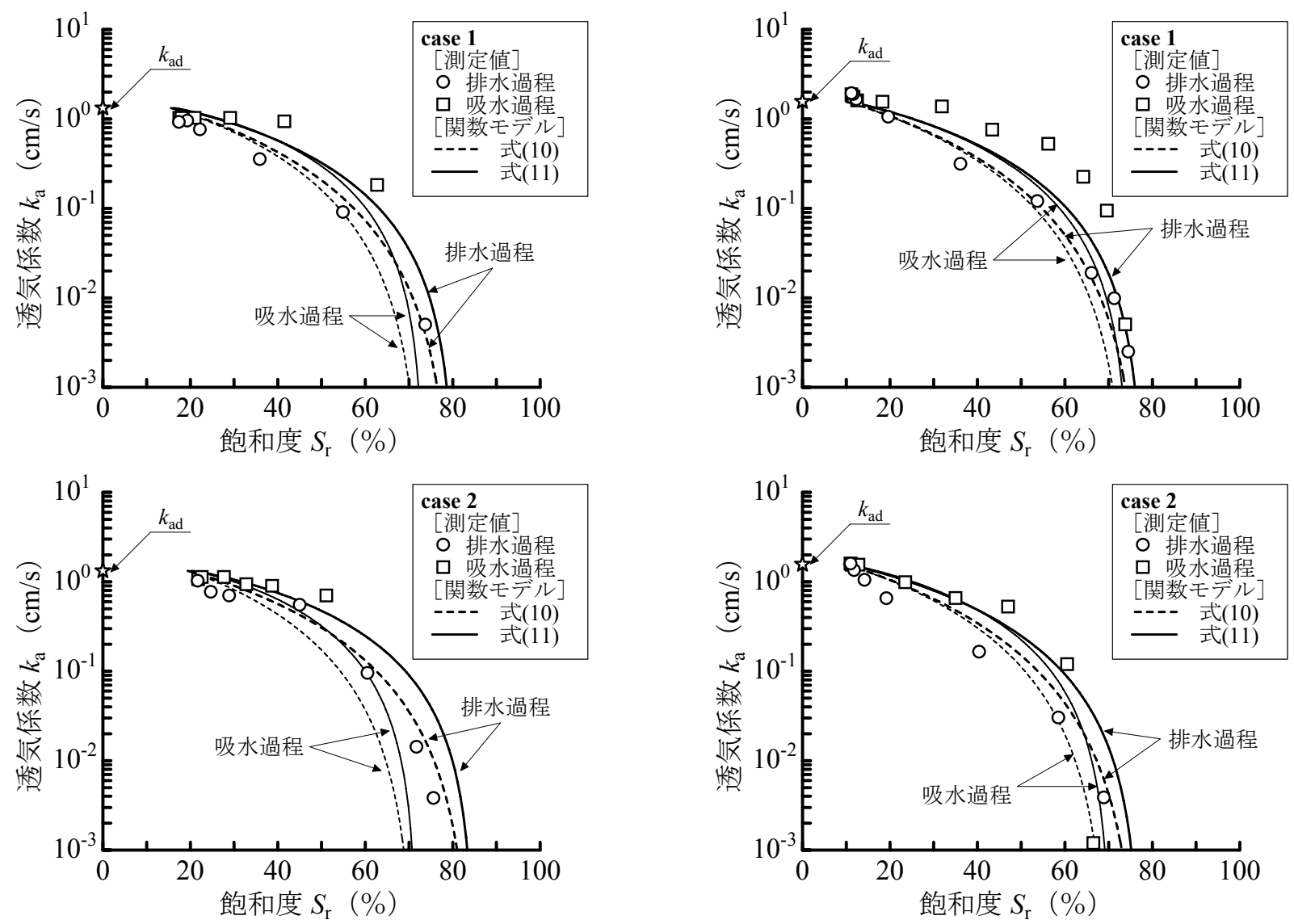

図－5(a） 飽和度と透気係数の関係(鳥取砂丘砂)

\section{図-5(c) 飽和度と透気係数の関係(豊浦砂)}
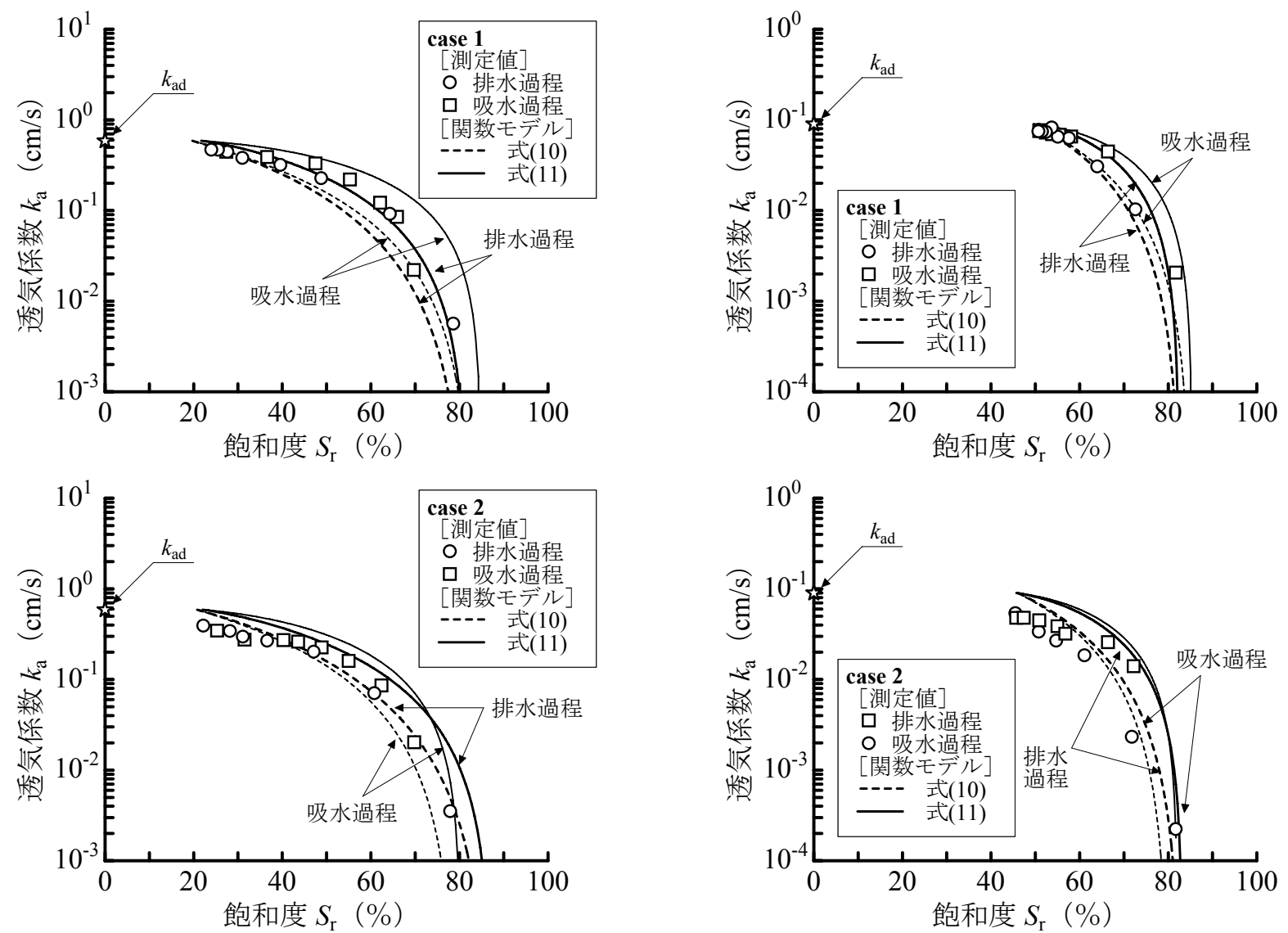

図－5(b) 飽和度と透気係数の関係(長良川砂質土)

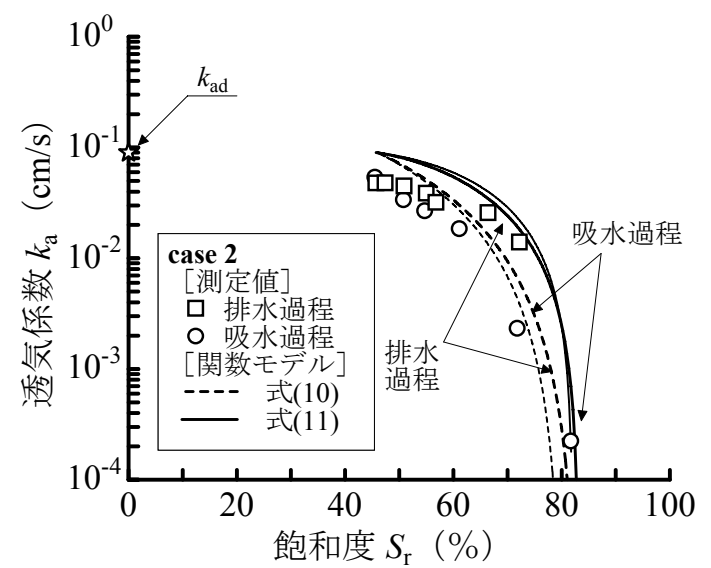

図－5(d)＼cjkstart飽和度と透気係数の関係(長良川シルト質土) 


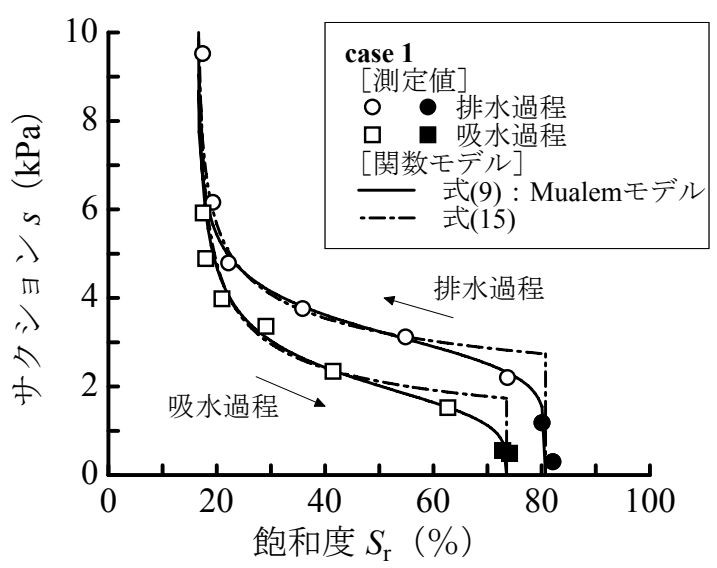

図－6 水分特性曲線モデルの比較(鳥取砂丘砂)

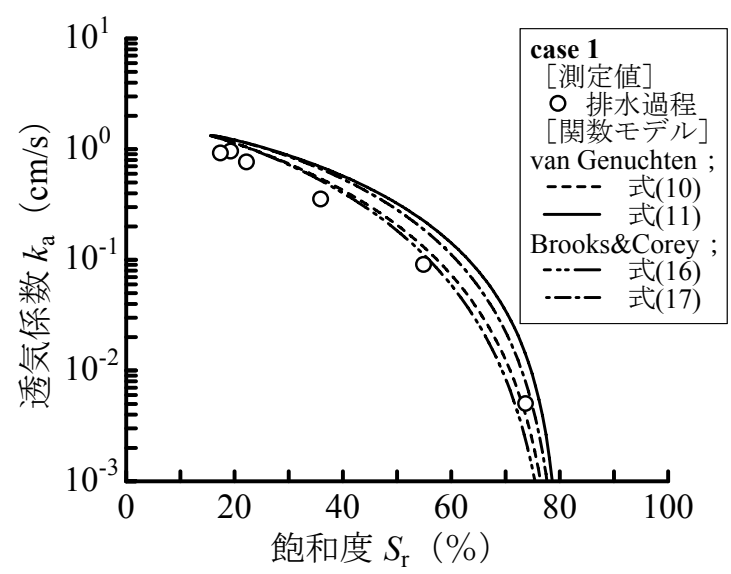

図－7 水分特性曲線モデルによる飽和度と透気係数 の関係の違い(鳥取砂丘砂(排水過程の場合))

による関係は，高飽和度側ではサクションを大きめ に与えて差が生じる.

次に，上述の式(8)の関係に Brooks \& Corey 式(15) の関係を代入して整理すると, Burdine モデルでは次 の式(16)によって透気係数 $k_{\mathrm{a}}$ が表され, Mualem モデ ルでは次式(17)の関係が得られる。

$$
\begin{gathered}
k_{\mathrm{a}} / k_{\mathrm{ad}}=\left(1-S_{\mathrm{e}}\right)^{2}\left(1-S_{\mathrm{e}}^{(2+\lambda) / \lambda}\right) \\
k_{\mathrm{a}} / k_{\mathrm{ad}}=\left(1-S_{\mathrm{e}}\right)^{0.5}\left(1-S_{\mathrm{e}}^{(1+\lambda) / \lambda}\right)^{2}
\end{gathered}
$$

なお，式(16)と式(17)をシルト質土について用いる場 合には，式中の有効飽和度 $S_{\mathrm{e}}$ を上述の式(14)による 修正有効飽和度 $S_{\mathrm{ep}}$ に置き換えたときの式を用いる. 図一7は，鳥取砂丘砂を例に，図一5(a) (case 1. 排水 過程)に対し，図ー6の整理で得られた $\lambda$ 值を用いて 式(16)と式(17)による関係を重ね合わせて示したも のである.図ー7のように, いずれの試料についても Brooks \& Corey 式(15)に基づいた式(16)と式(17)のそ れぞれによる関係は, van-Genuchten 式(9)に基づいた 式(10)と式(11)のそれぞれに比べて, 同じ飽和度のと
きの透気係数の值を若干小さく与える．また，図一6 のように式(15)による関係が高飽和度側で測定值や 式(9)による関係からずれが生じるため, 図一7におい ても高飽和度側で式(16)と式(17)による透気係数の 值は測定值や式(10), 式(11)による值から幾らかのず れが生じる。

水分特性曲線の表現式の違いによって飽和度と透 気係数の関係の差への影響はあまり大きくないが, 測定した水分特性曲線に適合性の高い表現式を選択 することが最良であると考えられる.

\section{5. 透気係数モデルの最適化}

上述の式(8)の空気流の屈曲に関する右辺第1括弧 の係数值 $\xi$ は, Burdine モデルでは $\xi=2$, Mualem モ デルでは $\xi=0.5$ と定められている. しかし, Dury ら は, 值が土質などによって異なる可能性があること を示した ${ }^{10)}$. 一方で， $\xi$ 值は，不飽和透水係数と飽和 度の関係を表した関数モデル式について検討された ものであるため ${ }^{13)}$, 14), 透気係数の場合について異な ることが予想される，以下では，透気係数に関する そ值の扱いなどを検討する.

\section{(1) 屈曲パラメーター}

式(10)と式(11)の右辺第1括弧の係数值2と 0.5 を 知パラメーター $\xi_{\mathrm{B}}$ と $\xi_{\mathrm{M}}$ に置き換え, また, 両式の炉 乾燥土の透気係数 $k_{\mathrm{ad}}$ を未知パラメーター $k_{\mathrm{ad}}$ *に置き 換えた各式を用いて, 図一5に示した飽和度と透気係 数の関係の測定值に対しフィッティングさせること によって， $\xi_{\mathrm{B}} ， \xi_{\mathrm{M}} ， k_{\mathrm{ad}}$ *をそれぞれ推定した。

図ー8は，豊浦砂を例に，図一5(c) (case 1)に対比し て，推定した $\xi_{\mathrm{B}}, \xi_{\mathrm{M}}, k_{\mathrm{ad}}$ *の值を用いたときの式(10) と式(11)の関係を測定值と併せて示したものである. これらの推定值を用いることによって, Burdine モデ ル式(10)と Mualem モデル式(11)の両者の関係はほぼ 合致する. 即ち, $\xi_{\mathrm{B}}, \xi_{\mathrm{M}}$ と $k_{\mathrm{ad}}$ *の值を最適化するこ とによって, 式(10)と式(11)のいずれの関係によって も飽和度と透気係数の関係を良好な精度で表現する ことが可能である。

\section{(2) 推定された $\boldsymbol{k}_{\mathrm{ad}} *$}

図ー9は，推定した $k_{\mathrm{ad}}$ *の值を図一5に示した炉乾 燥土の透気係数 $k_{\mathrm{ad}}$ の值に対して示したものである. 式(10)と式(11)を最適化したときの $k_{\mathrm{ad}}$ *值は測定した $k_{\mathrm{ad}}$ の值とほぼ合致し, 両式の $k_{\mathrm{ad}}$ の值には炉乾燥土の 透気係数の值を用いても良いことが確認される. 


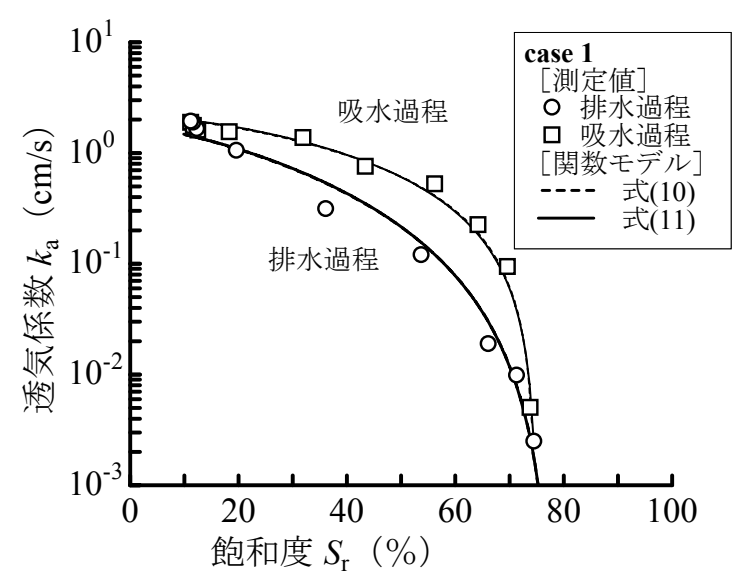

図ー8 透気係数モデル式(10)と式(11)の最適化(豊浦砂)

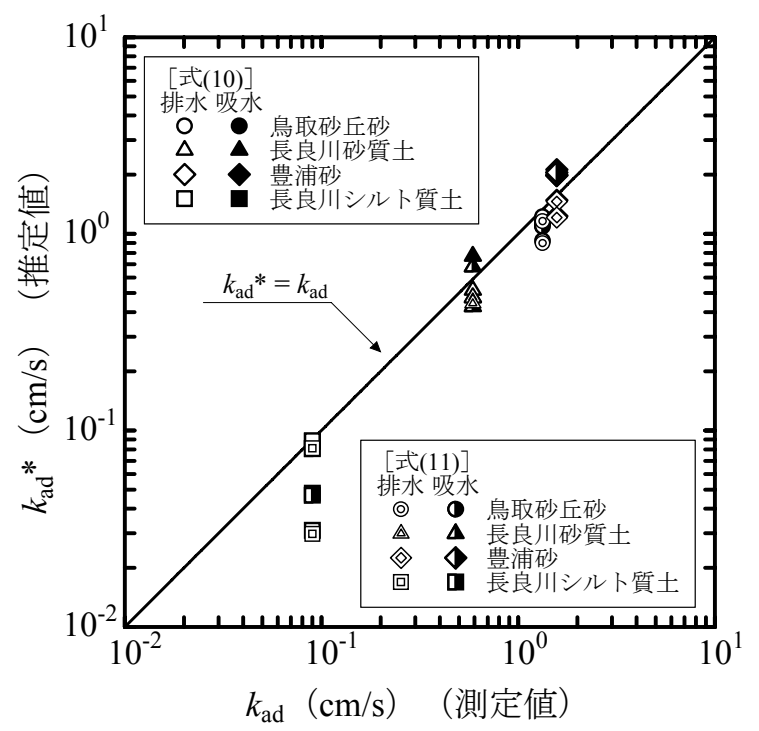

図-9 炉乾燥土の透気係数の測定值と推定值

\section{(3) $\xi_{\mathrm{B}}$ と $\xi_{\mathrm{M}}$ の最適値}

図ー10は，推定した $\xi_{\mathrm{B}}$ と $\xi_{\mathrm{M}}$ の值を両者の関係で 示したものである.排水過程では $\xi_{\mathrm{B}}=1.1 \sim 2.4$ の範囲, $\xi_{\mathrm{M}}=0.2 \sim 1.8$ の範囲で異なる值になり, 吸水過程では $\xi_{\mathrm{B}}=0.2 \sim 1.5, \xi_{\mathrm{M}}=-0.7 \sim 1.4$ の範囲にある. 平均值を試 算すると, 排水過程では, 砂質土で $\xi_{\mathrm{B}}=1.8, \xi_{\mathrm{M}}=0.9$, シルト質土で $\xi_{\mathrm{B}}=1.5, \xi_{\mathrm{M}}=0.8$, 吸水過程では, 砂質 土で $\xi_{\mathrm{B}}=1.1, \xi_{\mathrm{M}}=0.4$, シル卜質土で $\xi_{\mathrm{B}}=1.1, \xi_{\mathrm{M}}=0.6$ である。これらの平均值は，不飽和透水係数に関す る係数值 $\xi_{\mathrm{B}}=2, \xi_{\mathrm{M}}=0.5$ と比較すると, 排水過程では, $\xi_{\mathrm{B}}$ 值は小さめ, $\xi_{\mathrm{M}}$ 值は大きめになり, 吸水過程では, $\xi_{\mathrm{B}}$ 值は半分程度， $\xi_{\mathrm{M}}$ 值は同程度の大きさである。一 方, 図ー10に実線で示したように，排水と吸水過程

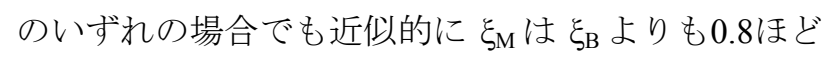
小さくなる関係にある.

ところで, Mualem モデルの $\xi_{\mathrm{M}}$ 值は負の值を示す ことがあり, このことは, 飽和度の増加に伴い屈曲 が少なくなることを表す。飽和度増加によって空気

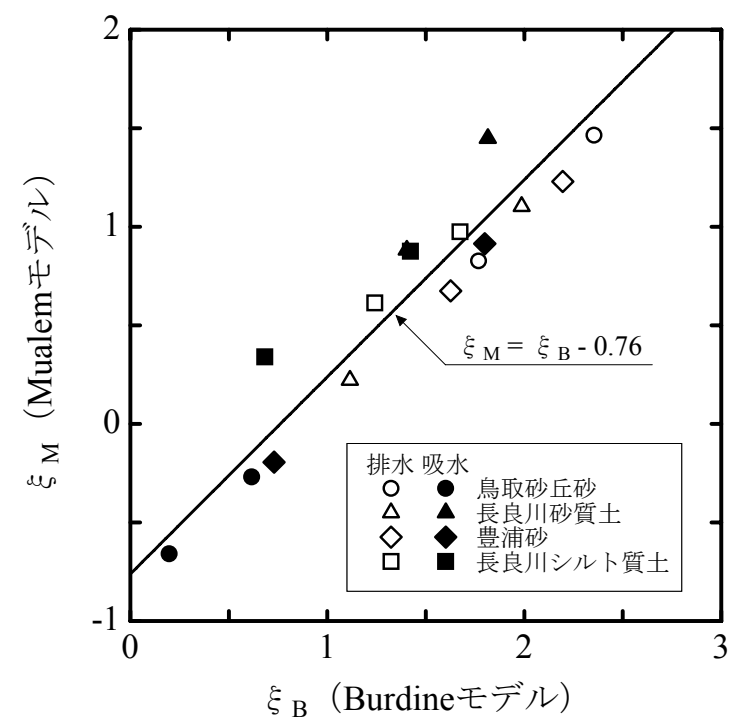

図ー10 屈曲パラメーター $\xi_{\mathrm{B}}$ と $\xi_{\mathrm{M}}$

で占められた間隙部分は減少し，空気流は探索する ように屈曲が多くなると考えられ， $\xi_{\mathrm{M}}$ が負值となる ことはそれと意味を異にする。従って，最適化した 式(10)や式(11)を用いる場合には，上述の図－8のよ うに両式による透気係数が合致することからも判断 すると, $\xi_{\mathrm{B}}$ が正值を示す Burdine モデル式(10)を用い てその值を的確に決定することで十分である。この とき, $\xi_{\mathrm{B}}$ 值は, 間隙の屈曲や連結性などによる透気 係数への影響を表した補正係数として扱われる.

\section{(4) 水分特性曲線と $\xi$ 值}

図ー11 (a)は，Burdine モデルの場合について，上 述の van-Genuchten による水分特性曲線表現式(9)に 含まれる $m_{\mathrm{B}}$ 值と $\xi_{\mathrm{B}}$ 值との関係を示したものであり, 図ー11(b)には, Mualem モデルの場合について $m_{\mathrm{M}}$ 值と $\xi_{M}$ 值との関係を示した.

図ー11 (a)によれば， $m_{\mathrm{B}}$ 值が 0.5 程度より大きい範 囲では, 吸水過程での $\xi_{\mathrm{B}}$ 值は排水過程でのものより 1.0 ほど小さいが， $m_{\mathrm{B}}$ 值が 0.5 程度より小さい範囲で は，排水と吸水過程での $\xi_{\mathrm{B}}$ 值はおよそ同じ大きさに なる傾向にあり約 1.5 の大きさである。一方，図一 11 (b) は図－11 (a) と類似した傾向にあり, $m_{\mathrm{M}}$ 值が 0.6 程度より小さい範囲では, 排水と吸水過程での $\xi_{\mathrm{M}}$ 值 は約 0.8 で同じ大きさになる傾向がある.

このように， $\xi_{\mathrm{B}}$ 值あるいは $\xi_{\mathrm{M}}$ 值は水分特性曲線の 形状に関わる $m_{\mathrm{B}}$ 值あるいは $m_{\mathrm{M}}$ 值と関連性があると みられ， $m_{\mathrm{B}}<0.5$ の範囲のとき $\xi_{\mathrm{B}} \fallingdotseq 1.5, m_{\mathrm{M}}<0.6$ のと き $\xi_{\mathrm{M}} \fallingdotseq 0.8$ とするのが目安であるが, それらの的確 な決定方法は今後の課題である. 


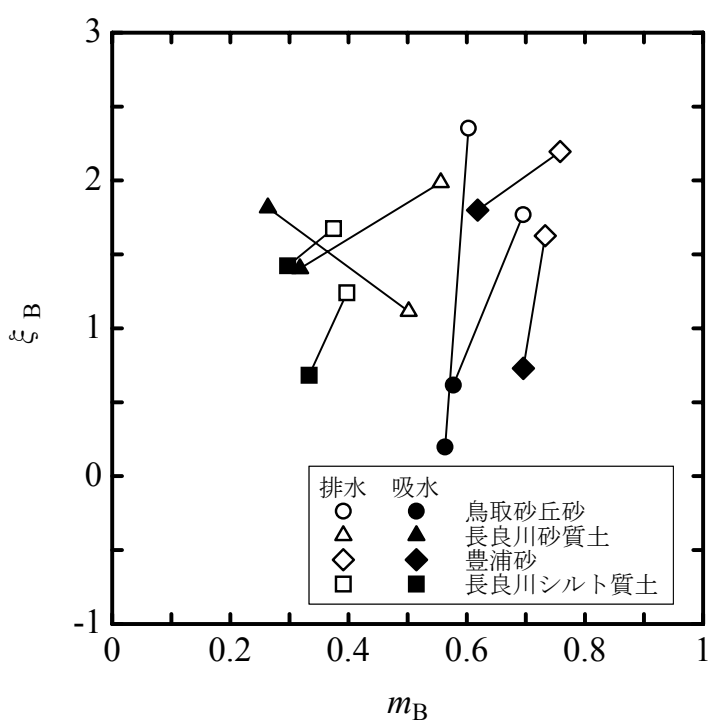

図ー11 (a) Burdine モデル式(10)での $m_{\mathrm{B}}$ 值と $\xi_{\mathrm{B}}$ 值

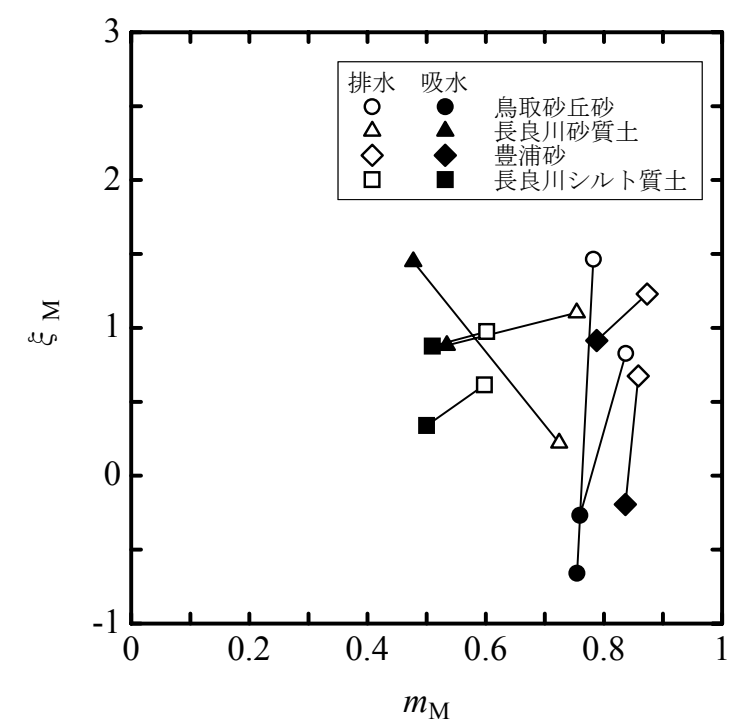

図ー11 (b) Mualem モデル式(11)での $m_{\mathrm{M}}$ 值と $\xi_{\mathrm{M}}$ 值

\section{6. あとがき}

本論文では，砂質土とシルト質土を対象に，水分 特性曲線と透気係数の実験的関係を調べるとともに, 間隙構造と透気係数と関連付けた Burdine モデルと Mualem モデルに基づき透気係数を表した従来の関 数モデル式の測定值への適合性などを分析した. そ の結果，以下の事項が判明した。

(1) Burdine モデルと Mualem モデルに van-Genuchten による水分特性曲線式を代入して誘導された飽和度 と透気係数の関係式(10)と式(11)について, 間隙の屈 曲の程度による透気係数への影響を表した両式の右 辺第1括弧を比較すると, 同じ有効飽和度のときに式 (10)の第1括弧の方が式(11)のものよりも透気係数を 小さめに与える. 間隙径分布と間隙の連結性に関わ
る第2括弧は，式(10)に比べると式(11)の方が透気係 数を小さめに与えるという特徴があった.

(2) 上述の式(10)と式(11)をシルト質土に適用する場 合には，式中の有効飽和度 $S_{\mathrm{e}}$ の值を式(14)によって 定義した修正有効飽和度 $S_{\mathrm{ep}}$ に置き換える必要性が 考えられた.シルト質土では, 水分特性曲線の変曲 点での飽和度 $S_{\mathrm{rp}}\left(<\right.$ 最大飽和度 $S_{\mathrm{rs}}$ )よりも低い飽和度 範囲で透気が生じるため, 砂質土の有効飽和度の定 義で用いた最大飽和度 $S_{\mathrm{rs}}$ に $S_{\mathrm{rp}}$ を代用した。

(3) 排水過程で測定した飽和度と透気係数の関係に 対して, Burdine モデルによる式(10)の関係が適合す る傾向にあった. 吸水過程では, 式(10)に比べると Mualem モデル式(11)による関係が測定值に近くなっ た. van-Genuchten による水分特性曲線式(9)は測定值 を良好に再現できるため, 式(10)や式(11)を測定值に 合致させるには，以下のように間隙の屈曲に関わる パラメーターその值の修正が必要であった。

(4) $\xi$ 值は, 式(10)と式(11)を測定值に合致するように 最適化したとき, 土質や排水・吸水の過程によって 異なることが得られた。不飽和透水係数について示 された Burdine の $\xi_{\mathrm{B}}=2$ と Mualem の $\xi_{\mathrm{M}}=0.5$ の值に対 比して, 透気係数については, 式(10)での $\xi_{\mathrm{B}}$ 值は, 排水過程で $1.1 \sim 2.4$, 吸水過程で $0.2 \sim 1.5$ の範囲にあ り, 式(11)での $\xi_{\mathrm{M}}$ 值は, 排水過程で $0.2 \sim 1.8$, 吸水過 程で-0.7〜1.4であった.

(5) 水分特性曲線の形状を決定する式(9)のパラメー ター $m_{\mathrm{B}}, m_{\mathrm{M}}$ の值と $\xi_{\mathrm{B}}, \xi_{\mathrm{M}}$ の值は関連性があるとみ られ，排水と吸水過程の両者で, $m_{\mathrm{B}}<0.5$ の範囲のと き $\xi_{\mathrm{B}}=1.5, m_{\mathrm{M}}<0.6$ のと $\xi_{\mathrm{M}}=0.8$ 程度にするのが目安 の一つであつた. $m_{\mathrm{B}}>0.5, m_{\mathrm{M}}>0.6$ の範囲のとき, $\xi_{\mathrm{B}}$ や $\xi_{\mathrm{M}}$ の值は両過程の間で差が大きくなる傾向にあっ た.

\section{参考文献}

1)西田義親，八木則男，二木幹夫 : 雨水浸透による地盤 内発生間隙圧と斜面安定, 土木学会論文報告集, No.262, pp.91-100, 1977.

2)Meiri, D. : Two-phase flow simulation of air storage in an aquifer, Water Resources Research, Vol.17, No.5, pp.1360-1366, 1981.

3)神谷浩二, Rully Bakrie, 本城勇介: 保水性を制御した 不飽和土の透気係数の測定, 土木学会論文集 C, Vol.62, No.3, pp.679-688, 2006.

4)Yoshimi, Y. and Osterberg, J. O. : Compression of partially saturated cohesive soils, Journal of the Soil Mechanics and Foundations Division, Proceedings of the American Society of Civil Engineers, Vol.89, No.SM4, pp.1-24, 1963.

5)長田 昇：土壤の通気性に関寸る実験的研究(I)一土壤 
の通気性について一, 農業土木研究別冊, No.7, pp.37-42, 1963.および，土壤の通気性に関する実験的研究(II) 一通気間ゲキの変移点について一, 農業土木研究別冊, No.7, pp.43-48, 1963.

6)Stylianou, C. and De Vantier, B. A. : Relative air permeability as function of saturation is soil venting, Journal of Environmental Engineering, Vol.121, No.4, pp.337-347, 1995.

7)Brooks, R. H. and Corey, A. T. : Properties of porous media affecting fluid flow, Journal of the Irrigation and Drainage Division, Proceedings of the American Society of Civil Engineers, Vol.92, No.IR2, pp.61-88, 1966.

8)Lenhard, R. J. and Parker, J. C. : A model for hysteretic constitutive relations governing multiphase flow: 2 . Permeability-saturation relations, Water Resources Research, Vol.23, No.12, pp.2197-2206, 1987.

9)Moldrup, P., Yoshikawa, S., Olesen, T., Komatsu, T. and Rolston, D. E. : Air permeability in undisturbed volcanic ash soils : predictive model test and soil structure fingerprint, Soil Science Society of America Journal, Vol.67, pp.32-40, 2003.

10)Dury, O., Fischer, U. and Schulin, R. : A comparison of relative nonwetting-phase permeability models, Water Resources Research, Vol.35, No.5, pp.1481-1493, 1999.

11)Chen, J., Hopmans, J. W. and Grismer, M. E. : Parameter estimation of two-fluid capillary pressure - saturation and permeability functions, Advance in Water Resources, Vol.22, No.5, pp.479-493, 1999.

12)Tuli, A. and Hopmans, J. W. : Effect of degree of fluid saturation on transport coefficients in disturbed soils, European Journal of Soil Science, Vol.55, pp.147-164, 2004.

13)Burdine, N. T. : Relative permeability calculations from pore size distribution data, Transactions of the American Institute of Mining and Metallurgical Engineers, Vol.198, pp.71-78, 1953.

14)Mualem, Y. : A new model for predicting the hydraulic conductivity of unsaturated porous media, Water Resources Research, Vol.12, pp.513-522, 1976.

15)宇野尚雄, 神谷浩二, 田中宏路：「空気圧入法」と「水 分法」による砂の間隙径分布, 土木学会論文集, No.603/III-44, pp.35-44, 1998.

16)van-Genuchten, M. T. : A closed-form equation for predicting the hydraulic conductivity of unsaturated soils, Soil Science Society of America Journal, Vol.44, pp.892-898, 1980.

17)Kosugi, K. : Lognormal distribution model for unsaturated soil hydraulic properties, Water Resources Research, Vol.32, pp.2697-2704, 1996.

18)河井克之, 軽部大蔵, 芦田 涉, 嘉戸善糺 : 間隙比の 影響を考慮した水分特性曲線モデル, 土木学会論文集, No.666/III-53, pp.291-302, 2000.

19)Wang, Z., Feyen, J., Nielsen, D. R. and van-Genuchten, M. T. : Two-phase flow infiltration equations accounting for air entrapment effects, Water Resources Research, Vol.33, No.12, pp.2759-2767, 1997.

(2007. 12. 5 受付)

\section{FUNCTIONAL MODELS TO PREDICT AIR PERMEABILITY COEFFICIENT FROM WATER CHARACTERISTIC CURVE OF UNSATURATED SOILS}

\section{Kohji KAMIYA and Mitsuhiro INOUE}

For predicting the air permeability coefficient from the water characteristic curve of unsaturated sandy and silty soils, the applicability of the air permeability model based on the Burdine theory and Mualem theory for expressing the relationship between the air permeability coefficient and the degree of water saturation is examined. As a result, the model based on the Burdine theory is more applicable during the drying process. However, the optimized parameter $\xi$-values for pore tortuosity in the models are varied for each soil and related the shape of the water characteristic curve. And then, it is recognized that the both models are good agreement with each other and fitted to the measured air permeability coefficient. 